\title{
Pengelompokan Kabupaten/Kota di Indonesia Berdasarkan Informasi Kemiskinan Tahun 2020 Menggunakan Metode K-Means Clustering Analysis
}

\author{
Rijalul Fikri ${ }^{*}$, Aswin Mushardiyanto ${ }^{2}$, Mochamad Naufal Laudza'Banin ${ }^{3}$, Kristiana Maureen ${ }^{4}$, Harry Patria ${ }^{5}$ \\ 1,2,3,4,5 Magister Manajemen Teknologi, Institut Teknologi Sepuluh Nopember, Surabaya, Indonesia \\ (*rijalul.fikri.ap1@gmail.com)
}

\begin{abstract}
Abstrak - Berdasarkan dataset tentang informasi kemiskinan kabupaten/kota tahun 2020 yang dikeluarkan oleh Badan Pusat Statistik Indonesia, dipilih variabel bebas sebanyak dua puluh variabel yang digunakan dalam penelitian ini. Kemudian dilakukan uji korelasi antar variabel bebas tersebut dan diketahui terdapat variabel yang berkorelasi dikategorikan berkorelasi sangat tinggi, dengan nilai korelasi sebesar 0,921 (Persentase Penduduk Miskin - P1 (Poverty Gap Index)) dan 0,964 (P1 (Poverty Gap Index) - P2 (Proverty Severity Index)). Variabel yang memiliki korelasi sangat tinggi jika digunakan akan menyebabkan terjadinya multikolinearitas, sehingga opsi untuk menghilangkan multikolinearitas adalah dengan menggunakan Principal Component Analysis (PCA). Dengan menggunakan Proporsi Kumulatif Varians dan minimum persentase keragaman data sebesar $80 \%$ maka didapatkan output berupa dimensi data baru PCA sebanyak tiga dimensi data atau tiga variabel bebas baru. Dengan menggunakan variabel input baru berupa PCA 0, PCA 1 dan PCA 2 dilakukanlah penentuan jumlah cluster dengan metode Silhouette Coefficient dan analisa clustering menggunakan metode K-Means didapatkanlah empat kelompok/cluster, dengan jumlah anggota cluster 1 sebanyak 117 Kabupaten/Kota, cluster 2 sebanyak 154 Kabupaten/Kota, cluster 3 sebanyak 173 Kabupaten/Kota dan cluster 4 sebanyak 70 Kabupaten/Kota.
\end{abstract}

Kata kunci: clustering; kemiskinan; K-Means

\section{PENDAHULUAN}

Badan Pusat Statistik (BPS) telah merilis beragai variabel terkait informasi kemiskinan Kabupaten/Kota di Indonesia tahun 2020. Berdasarkan data tersebut, diketahui bahwa angka kemiskinan di Indonesia bertambah kurang lebih 2,76 juta jiwa atau meningkat sebesar 10,19 persen dibandingkan tahun 2019. Data kemiskinan di setiap Kabupaten/Kota se-Indonesia berbeda-beda. Perbedaan ini disebabkan oleh berbagai indikator seperti: Jumlah penduduk yang berbeda antar daerah, pendapatan perkapita yang berbeda, angka melek huruf dan akses pendidikan, akses untuk mendapatkan air bersih dan layak dan lain sebagainya. Dikarenakan banyaknya indikator pendukung tersebut yang perlu diperhatikan, maka penanganan dalam mengatasi masalah kemiskinan juga dapat berbeda-beda (Febianto, 2019). Oleh karena itu, diperlukan analisa yang bertujuan untuk mengelompokkan indikator-indikator kemiskinan di tingkat Kabupaten/Kota berdasarkan secara objektif. Salah satu metode analisa yang dapat digunakan untuk mengelompokkan angka kemiskinan dan berbagai indikator lainnya menggunakan metode clustering.

Metode analisa clustering merupakan analisa yang bertujuan untuk memetakan atau mengkategorikan objek data berdasarkan kesamaan karakteristik diantara objek data tersebut (Febianto, 2019). Sehingga terbentuk kelompok data atau cluster tersebut dapat menjadi acuan dalam pengambilan keputusan oleh stakeholder. Dalam penerapannya, Analisa clustering memiliki beberapa metode yang dapat digunakan berdasarkan algoritmanya seperti K-Means, Hierarchical Clustering, Fuzzy C Means. Metode yang digunakan dalam penelitian ini adalah analisis clustering dengan metode $K$-Means. Untuk menganalisa data digunakan software KNIME Analytics yang merupakan tools dalam melakukan analisa data dengan pendekatan workflow.

Penelitian ini bertujuan untuk mengelompokkan Kabupaten / Kota se-Indonesia berdasarkan kedekatan nilai dari berbagai variabel kemiskinan yang dirilis oleh BPS pada tahun 2020. Sehingga dengan hasil penelitian ini, pemerintah dan atau lembaga sosial swasta dapat memanfaatkan data hasil pengelompokkan / clustering Kabupaten / Kota yang terbentuk dalam mengambil keputusan dan kebijakan terbaik untuk penanganan masalah kemiskinan di Indonesia. Serta dapat menjadi refrensi bagi akademisi dan dunia pendidikan untuk dapat mengembangkan penelitian dengan lingkup data dan wilayah lainnya. 


\section{STUDI LITERATUR}

\section{A. Analisa Clustering}

Sebuah cluster terdiri dari berbagai objek yang serupa dan dikumpulkan atau dikelompokkan secara bersama. Analisa clustering sendiri merupakan studi formal tentang algoritma dan metode untuk mengelompokkan atau mengklasifikasikan suatu objek. Analisa clustering tidak menggunakan label kategori yang menandai objek dengan pengidentifikasi sebelumnya. Tidak adanya label kategori yang menjadikan analisa clustering berbeda dengan analisa diskriminan (pengenalan pola atau analisa keputusan). Tujuan dari analisa clustering hanya bertujuan untuk menemukan organisasi data yang sesuai dan valid serta bukan untuk menetapkan aturan dalam memisahkan data masa depan ke dalam kategori (James A K, 1988).

\section{B. Analisa Korelasi}

Analisa Korelasi berasal dari kata correlation analysis, digunakan untuk mengetahui arah hubungan, kuat hubungan, dan signifikansi kuatnya hubungan antara dua variabel atau lebih, dimana dalam ukuran statistik disebut koefisien korelasi (r). Dua variabel dikatakan berkorelasi apabila perubahan pada salah satu variabel disertai dengan perubahan pada variabel lainnya secara linear, baik dalam arah yang sama ataupun arah yang sebaliknya (Roflin, 2021).

Terdapat standar skala aturan praktis yang dapat digunakan untuk mengevaluasi dan menginterpretasikan nilai dari koefisien korelasi, dimana standar tersebut dapat dilihat pada tabel berikut (Asuero, 2006):

Tabel 1

Interpretasi Nilai Korelasi

\begin{tabular}{|l|l|}
\hline \multicolumn{1}{|c|}{ Nilai Korelasi (r) } & \multicolumn{1}{c|}{ Interpretasi } \\
\hline 0,90 sampai 1,00 & Korelasi Sangat Tinggi \\
\hline 0,70 sampai 0,89 & Korelasi Tinggi \\
\hline 0,50 sampai 0,69 & Korelasi Moderat \\
\hline 0,30 sampai 0,49 & Korelasi Lemah \\
\hline 0,00 sampai 0,29 & Sedikit jika ada korelasi \\
\hline
\end{tabular}

Variabel yang berkorelasi sangat tinggi dapat menyebabkan terjadinya multikolineritas. Multikolinearitas sendiri dapat menyebabkan hasil prediksi atau analisa kita akan menjadi tidak akurat atau tidak dapat di interpretasikan (Jamal, 2017).

\section{Principal Components Analysis (PCA)}

Principal Component Analysis (PCA) merupakan salah satu teknik statistika multivaria yang digunakan untuk menyederhanakan suatu data dengan cara mentransformasi data secara linear sehingga terbentuk sistem koordinat baru dengan varian maksimum tanpa mengurangi karakteristik data tersebut secara signifikan. PCA juga sering digunakan untuk menghindari masalah multikolinearitas yang terjadi karena adanya korelasi antar variabel bebas (Yusuf, 2018).

Dalam melakukan analisa PCA, terdapat proses penetuan dimensi output yang nantinya menjadi variabel bebas baru. Nugroho (2008) menjelaskan bahwa pada umumnya terdapat tiga metode yang biasa digunakan dalam menentukan dimensi output, yaitu yang pertama didasarkan pada kumulatif proporsi varians / keragaman. Dimana minimum presentasi keragaman dalam menejelaskan data harus ditetapkan terlebih dahulu. Tidak ada patokan baku dalam menentukan batas minimum presentase tersebut, sebagaian ada yang menyebut $70 \%, 80 \%$ dan $90 \%$.

Metode kedua menggunakan matriks korelasi dengan cara variabel asal di transformasi menjadi variabel baru yang memiliki keragaman yang sama, yaitu satu. Sehingga jika ada komponen utama yang ragamnya kurang dari satu dianggap memiliki kontribusi yang kurang. Dengan cara ini, komponen yang berpadanan dengan akar ciri kurang dari satu tidak digunakan.

Metode ketiga adalah penggunaan grafik yang disebut scree plot. Scree plot merupakan plot antara akar ciri $\lambda_{\mathrm{k}}$ dengan $\mathrm{k}$. Dengan menggunakan metode ini, banyaknya komponen utama yang dipilih, yaitu k, adalah jika pada titik k tersebut plotnya curam ke kiri tapi tidak curam ke kanan. 


\section{Silhouette Coefficient}

Pada dasarnya penentuan jumlah kluster bersifat subjektif atau tergantung pada pemahaman bisnis dan keperluan proses bisnis itu sendiri. Tetapi terdapat beberapa metode yang dapat digunakan untuk menentukan jumlah kluster terbaik, salah satunya menggunakan Silhouette Coefficient.

Silhouette Coefficient sendiri merupakan metrik yang berguna untuk mengevaluasi kualitas hasil clustering berdasarkan lebar silhouette. Secara khusus lebar silhouette S(i) untuk entitas i didefinisikan sebagai berikut.

$$
s(i)=\frac{b(i)-a(i)}{\max (a(i), b(i))}
$$

di mana a adalah jarak rata-rata intra-cluster dan b adalah jarak rata-rata antar-cluster ke cluster terdekat. Skor dapat berkisar dari -1.0 hingga 1.0, sedangkan semakin tinggi skor, semakin baik sebuah kluster (Kodinariyah, 2013).

\section{E. K-Means}

K-means adalah algoritma pengelompokan partisi sederhana berbasis prototipe yang mencoba menemukan $\mathrm{K}$ cluster yang tidak tumpang tindih. Cluster ini diwakili oleh centroid mereka (centroid cluster biasanya ratarata dari titik-titik dalam cluster itu). Proses clustering K-means adalah sebagai berikut. Centroid awal K pertama dipilih, di mana $\mathrm{K}$ ditentukan oleh pengguna dan ditunjukkan jumlah cluster yang diinginkan. Setiap titik dalam data kemudian ditetapkan ke centroid terdekat, dan setiap kumpulan titik yang ditetapkan ke centroid membentuk cluster. Centroid dari setiap cluster kemudian diperbarui berdasarkan poin yang ditetapkan untuk cluster tersebut. Proses ini berulang sampai tidak ada titik perubahan cluster (Wu, 2012).

\section{METODOLOGI}

\section{A. Dataset Penelitian}

Penelitian ini menggunakan dataset Informasi Kemiskinan Kabupaten / Kota Tahun 2020 yang dikeluarkan oleh Badan Pusat Statistik Indonesia. Dimana variabel yang digunakan dalam penelitian ini adalah sebagai berikut. 
Tabel 2

Variabel Dataset Informasi Kemiskinan Kabupaten / Kota Tahun 2020

\begin{tabular}{|c|c|c|c|}
\hline No & Nama Variabel & No & Nama Variabel \\
\hline 1 & Jumlah Penduduk Miskin & 11 & $\begin{array}{l}\text { Angka Partisipasi Sekolah Penduduk Miskin Menurut } \\
\text { Kabupaten/Kota dan Golongan Umur, Tahun } 2020 \\
\text { (13-15 th ) }\end{array}$ \\
\hline 2 & Persentase Penduduk Miskin & 12 & $\begin{array}{l}\text { Persentase Penduduk Miskin Usia } 15 \text { Tahun ke Atas } \\
\text { Menurut Kabupaten/Kota dan Status Bekerja, Tahun } \\
2020 \\
\text { ( Tidak Bekerja *termasuk pengangguran dan bukan } \\
\text { angkatan kerja ) }\end{array}$ \\
\hline 3 & $\begin{array}{l}\text { P1 (Poverty Gap Index) / Indeks Kedalaman } \\
\text { Kemiskinan }\end{array}$ & 13 & $\begin{array}{l}\text { Persentase Penduduk Miskin Usia } 15 \text { Tahun ke Atas } \\
\text { Menurut Kabupaten/Kota dan Status Bekerja, Tahun } \\
2020 \\
\text { ( Bekerja di Sektor Informal ) }\end{array}$ \\
\hline 4 & $\begin{array}{l}\text { P2 (Proverty Severity Index) / Indeks Keparahan } \\
\text { Kemiskinan }\end{array}$ & 14 & $\begin{array}{l}\text { Persentase Penduduk Miskin Usia } 15 \text { Tahun ke Atas } \\
\text { Menurut Kabupaten/Kota dan Status Bekerja, Tahun } \\
2020 \\
\text { ( Bekerja di Sektor Formal ) }\end{array}$ \\
\hline 5 & $\begin{array}{l}\text { Persentase Penduduk Miskin Usia } 15 \text { Tahun ke Atas } \\
\text { Menurut Kabupaten/Kota dan Pendidikan yang } \\
\text { Ditamatkan, Tahun } 2020(<\text { SD })\end{array}$ & 15 & $\begin{array}{l}\text { Persentase Penduduk Miskin Usia } 15 \text { Tahun ke Atas } \\
\text { Menurut Kabupaten/Kota dan Sektor Bekerja, Tahun } \\
2020 \\
\text { ( Bekerja di Sektor Pertanian ) }\end{array}$ \\
\hline 6 & $\begin{array}{l}\text { Persentase Penduduk Miskin Usia } 15 \text { Tahun ke Atas } \\
\text { Menurut Kabupaten/Kota dan Pendidikan yang } \\
\text { Ditamatkan, Tahun } 2020 \text { ( Tamat SD/SLTP ) }\end{array}$ & 16 & $\begin{array}{l}\text { Persentase Penduduk Miskin Usia } 15 \text { Tahun ke Atas } \\
\text { Menurut Kabupaten/Kota dan Sektor Bekerja, Tahun } \\
2020 \\
\text { ( Bekerja Bukan di Sektor Pertanian ) }\end{array}$ \\
\hline 7 & $\begin{array}{l}\text { Persentase Penduduk Miskin Usia } 15 \text { Tahun ke Atas } \\
\text { Menurut Kabupaten/Kota dan Pendidikan yang } \\
\text { Ditamatkan, Tahun } 2020 \\
(\text { SLTA +) }\end{array}$ & 17 & $\begin{array}{l}\text { Persentase Pengeluaran Perkapita untuk Makanan } \\
\text { Menurut Kabupaten/Kota dan Status Miskin, Tahun } \\
2020 \\
\text { ( Miskin ) }\end{array}$ \\
\hline 8 & $\begin{array}{l}\text { Angka Melek Huruf Penduduk Miskin Menurut } \\
\text { Kabupaten/Kota dan Golongan Umur, Tahun } 2020 \\
\text { ( } 15-24 \text { th ) }\end{array}$ & 18 & $\begin{array}{l}\text { Persentase Pengeluaran Perkapita untuk Makanan } \\
\text { Menurut Kabupaten/Kota dan Status Miskin, Tahun } \\
2020 \\
\text { ( Tidak Miskin) }\end{array}$ \\
\hline 9 & $\begin{array}{l}\text { Angka Melek Huruf Penduduk Miskin Menurut } \\
\text { Kabupaten/Kota dan Golongan Umur, Tahun } 2020 \\
(15-55 \text { th })\end{array}$ & 19 & $\begin{array}{l}\text { Persentase Rumah Tangga Miskin yang Menggunakan } \\
\text { Air Layak Menurut Kabupaten/Kota, Tahun } 2020\end{array}$ \\
\hline 10 & $\begin{array}{l}\text { Angka Partisipasi Sekolah Penduduk Miskin Menurut } \\
\text { Kabupaten/Kota dan Golongan Umur, Tahun } 2020 \\
(7-12 \text { th ) }\end{array}$ & 20 & $\begin{array}{l}\text { Persentase Rumah Tangga Miskin yang Menggunakan } \\
\text { Jamban Sendiri/Bersama Menurut Kabupaten/Kota, } \\
\text { Tahun } 2020\end{array}$ \\
\hline
\end{tabular}

\section{B. Analisa Korelasi Variabel Bebas Asal}

Korelasi antar variabel dataset Informasi Kemiskinan Kabupaten / Kota menggunakan software KNIME Analytics dapat dilihat pada gambar 1 


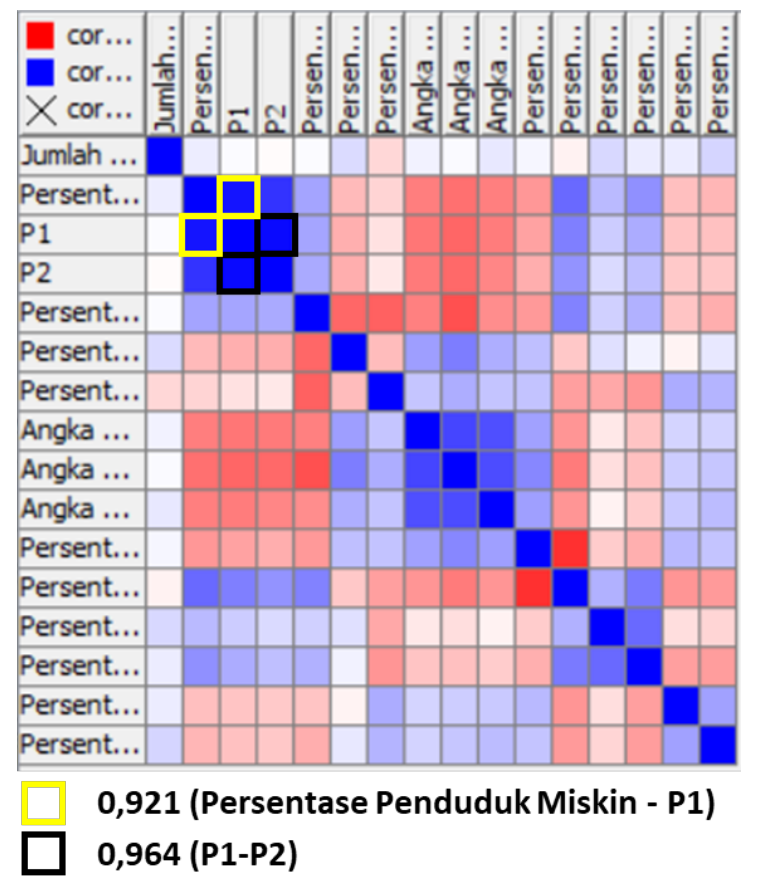

Gambar 1. Matriks Korelasi Antar Variabel Asal

Skala matriks korelasi menggunakan menggunakan software KNIME Analytics ditampilkan -1 sampai +1 . Dimana -1 berarti berkorelasi negatif sempurna dan +1 berarti berkorelasi positif sempurna. Variabel yang berkorelasi sangat tinggi dapat menyebabkan terjadinya multikolineritas. Multikolinearitas sendiri dapat menyebabkan hasil prediksi atau analisa kita akan menjadi tidak akurat atau tidak dapat di interpretasikan. Nilai Korelasi antar variabel dikategorikan Sangat Tinggi minimal sebesar 0,9 (Asuero, 2006). Berdasarkan matriks korelasi pada gambar 1, terdapat korelasi antar variabel dengan kategori Sangat Tinggi, yaitu :

Tabel 3

Daftar Variabel Yang Memiliki Korelasi Dengan Kategori Sangat Tinggi

\begin{tabular}{|l|l|l|c|}
\hline No & \multicolumn{1}{|c|}{ Variabel Pertama } & \multicolumn{1}{|c|}{ Variabel Kedua } & Nilai Korelasi \\
\hline 1 & Persentase Penduduk Miskin & P1 (Poverty Gap Index) & 0,921 \\
\hline 2 & P1 (Poverty Gap Index) & P2 (Proverty Severity Index) & 0,964 \\
\hline
\end{tabular}

Pada dasarnya untuk menangani korelasi ada banyak cara diantaranya dengan cara mengeliminasi variabel yang berkorelasi sangat tinggi atau bisa juga dengan menggabungkan variabel yang berkorelasi sangat tinggi menggunakan PCA (Principal Component Analysis) (Jamal, 2017).

\section{PCA (Principal Component Analysis)}

PCA (Principal Component Analysis) pada dasarnya bertujuan untuk mereduksi dimensi data agar lebih sederhana atau lebih kecil. Hal tersebut menyebabkan adanya transformasi dari variabel bebas asal menjadi variabel bebas baru dan membuat variabel bebas baru tersebut tidak berkorelasi sama sekali dan tidak menyebabkan multikolinearitas.

Metode yang bisa diterapkan dalam menentukan banyaknya komponen utama sebagai variabel bebas baru salah satunya dengan menggunakan Proporsi Kumulatif Varians. Dalam kasus ini penetuan jumlah dimensi variabel PCA menggunakan pendekatan Proporsi Kumulatif Varians dengan syarat dimensi variabel bebas baru harus dapat menejelaskan minimum $80 \%$ keragaman data. Dengan menggunakan software KNIME Analytics dapat dilakukan dengan menggunakan tool "PCA Apply" sebagai berikut. 


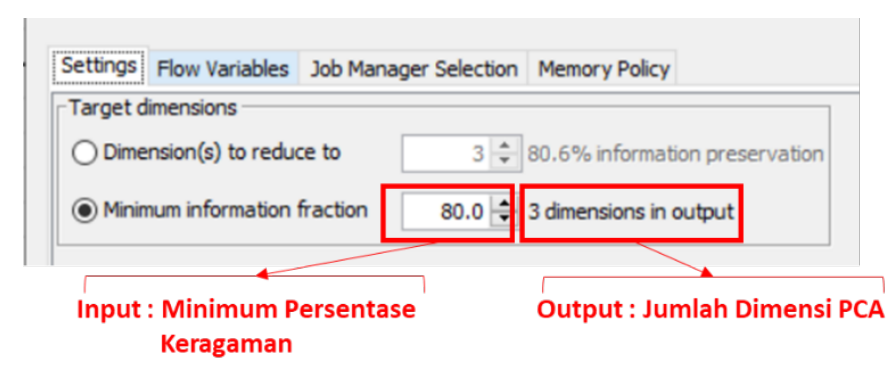

Gambar 2. Penggunaan Tool "PCA Apply” Pada Software KNIME Analytics Dalam Menentukan Jumlah Dimensi

Pada gambar 2 dapat dilihat bahwa dengan memilih Radio Button "Minimum Information Fraction" dapat memasukan nilai input berupa minimum persentase keragaman data yang diinginkan. Dengan menggunakan dataset Informasi Kemiskinan Kabupaten / Kota dan dengan minimum persentase keragaman data sebesar $80 \%$ maka didapatkan output berupa dimensi data baru PCA sebanyak tiga variabel bebas baru. Tiga variabel baru tersebut diberi nama PCA 0, PCA 1 dan PCA 2. Ilustrasi transformasi reduksi dimensi menggunakan PCA digambarkan pada gambar 3.

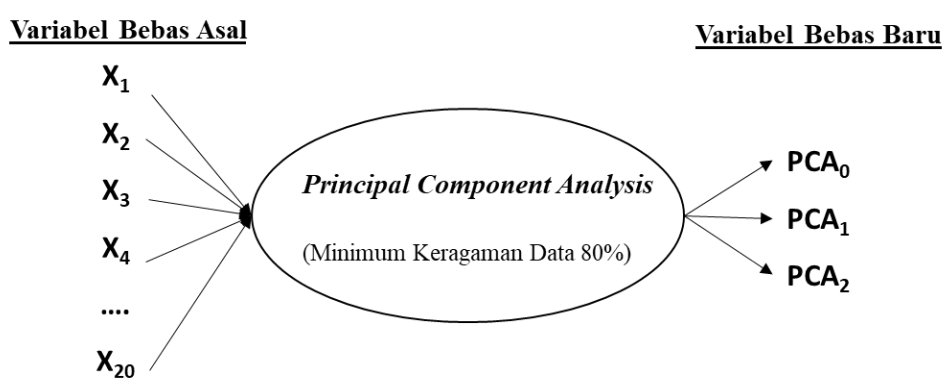

Gambar 3. Transformasi Reduksi Dimensi Menggunakan PCA (Principal Component Analysis)

Kemudian dari ke tiga variabel baru tersebut, dilakukan kembali uji korelasi untuk membuktikan bahwa sudah tidak ada multikolinearitas, dan didapatkan hasil seperti berikut.

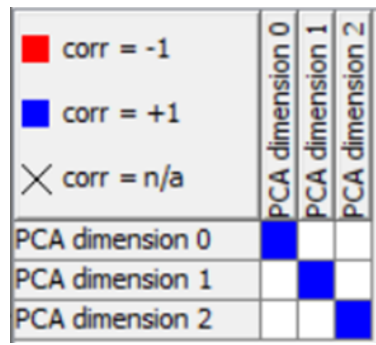

Gambar 4. Matriks Korelasi Antar Variabel Hasil PCA

Dari gambar 4 diketahui bahwa tidak ada korelasi antar variabel baru (PCA 0, PCA 1 dan PCA 2), sehingga variabel baru hasil dari proses PCA tersebut dapat digunakan untuk analisa clustering selanjutnya

\section{Penentuan Jumlah Cluster}

Pada software KNIME Analytics terdapat node Silhouette Coefficient yang dapat digunakan dalam pengukuran kualitas jumlah cluster. Hasil Silhouette Coefficient dengan variabel bebas PCA 0, PCA 1 dan PCA 2 ditampilkan pada gambar 5. 


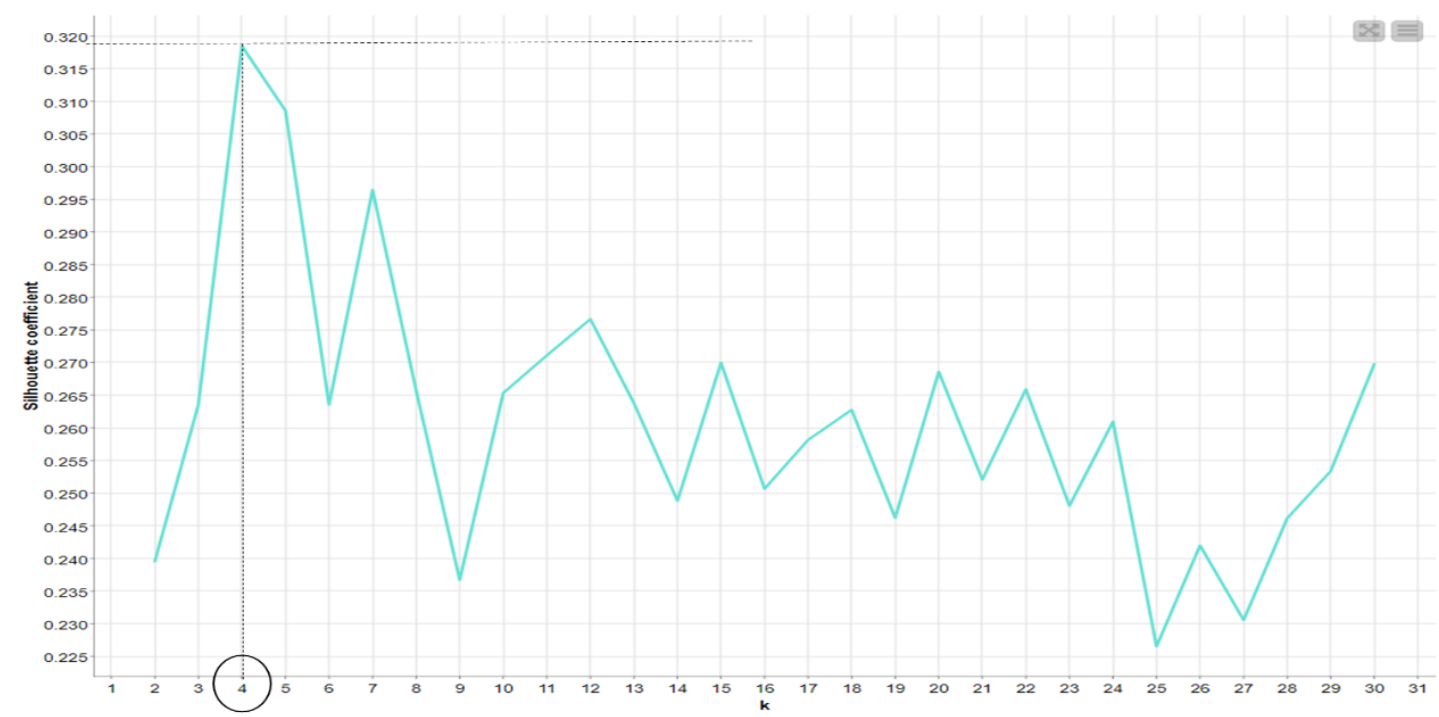

Gambar 5. Hasil Silhouette Coefficient

Grafik yang ditunjukkan pada gambar 5 dapat dilihat hasil silhouette coefficient untuk masing- masing cluster. Dimana nilai silhouette coefficient tertinggi ada pada nilai 0,320 dengan nilai $\mathrm{k}=4$ atau dalam arti cluster terbaik yang terpilih berjumlah 4 (empat) cluster.

\section{E. Analisa Clustering K Means}

Langkah terakhir adalah melakukan analisa clustering dengan menggunakan metode $\mathrm{K}$ Means dengan menggunakan software KNIME Analytics. Disusunlah workflow K Means Clustering Model seperti pada gambar 6 sebagai berikut :

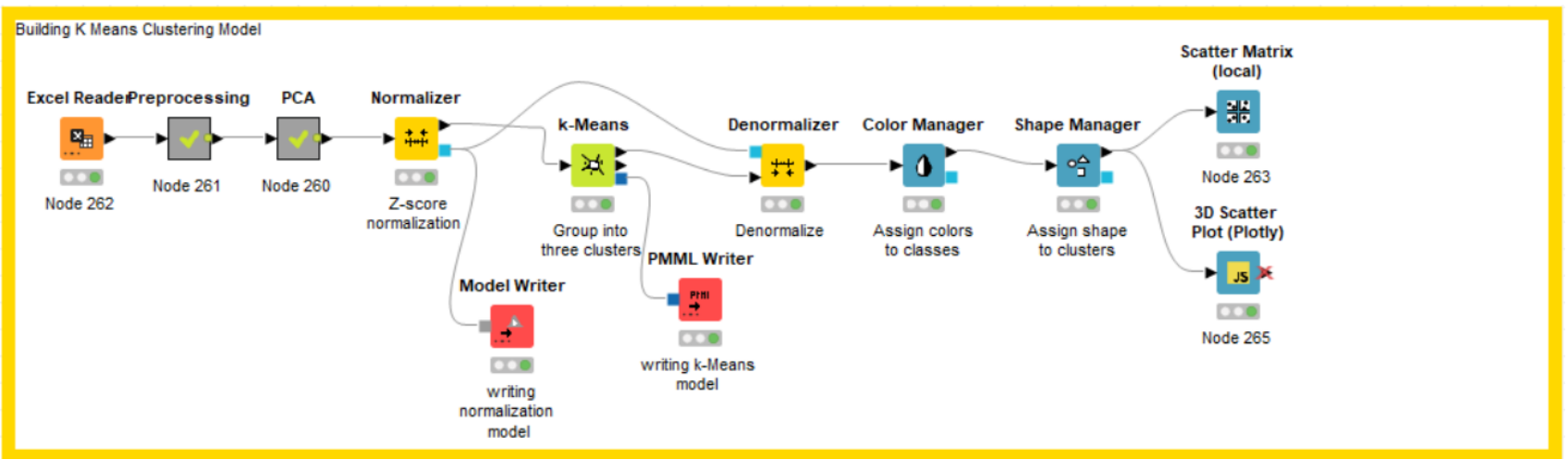

Gambar 6. K Means Clustering Model menggunakan software KNIME Analytics

\section{HASIL DAN DISKUSI}

\section{A. Hasil Analisa Clustering Kmeans}

Dengan menggunakan variabel bebas dari hasil analisa PCA (Principal Component Analysis) yang menghasilkan tiga buah variabel (PCA 0, PCA 1 dan PCA 2) maka dilakukan analisa clustering dengan menggunakan metode K Means. Didapatkan hasil clustering dalam scatter plot 3D (tiga dimensi) sebagai berikut. 


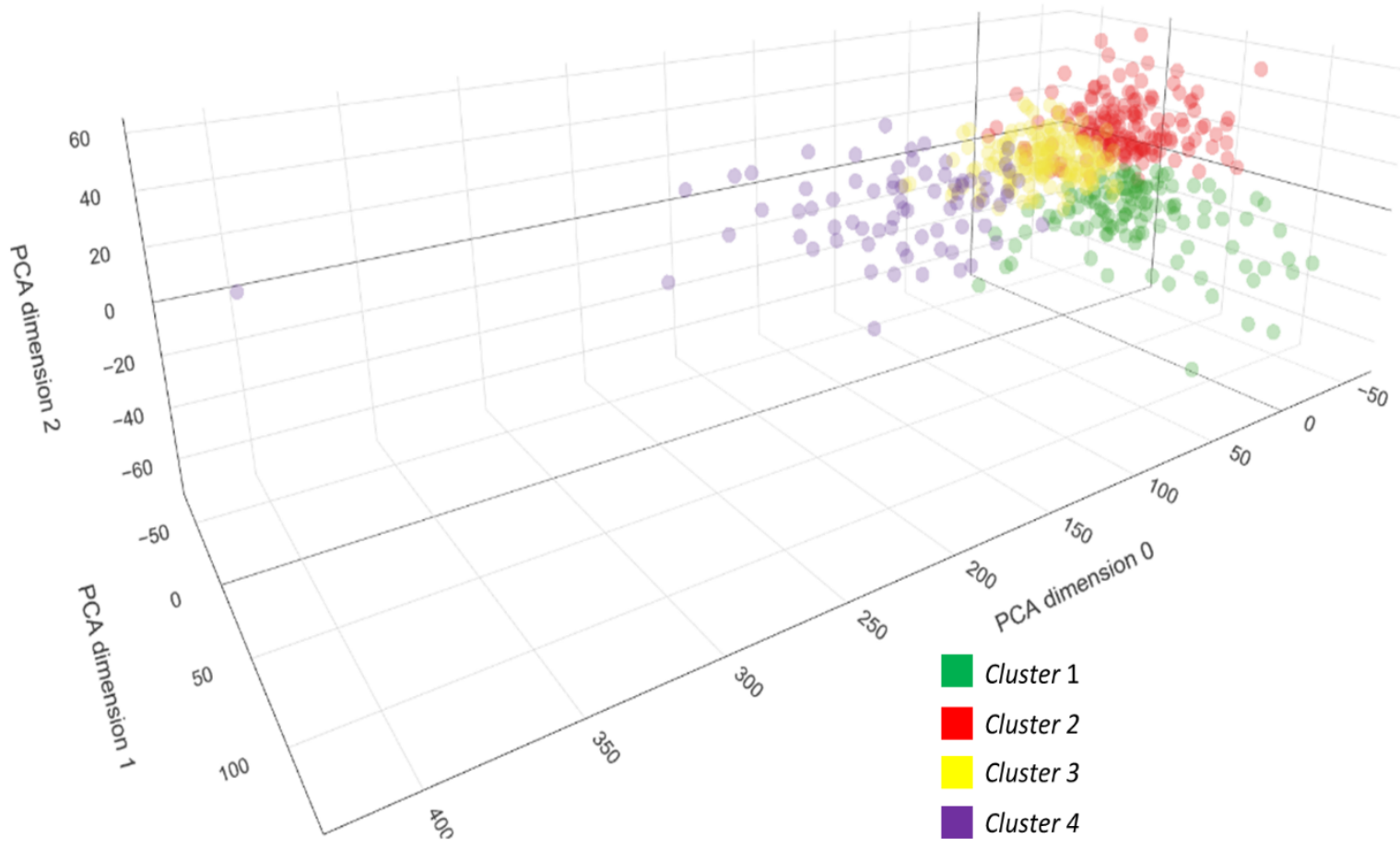

Gambar 7. Scatter Plot 3D Analisa Clustering K Means

Terlihat dari gambar 7 terjadi pengelompokan atau clustering Kabupaten / Kota di Indonesia menjadi empat cluster baru. Masing- masing cluster memiliki jumlah anggota Kabupaten / Kota sebagai berikut.

Tabel 4

Anggota Hasil Clustering

\begin{tabular}{|c|c|c|}
\hline $\begin{array}{c}\text { Nama } \\
\text { Cluster }\end{array}$ & $\begin{array}{c}\text { Jumlah Anggota } \\
\text { Cluster }\end{array}$ & Sampel Anggota Cluster (Kabupaten / Kota) \\
\hline Cluster 1 & 117 & $\begin{array}{c}\text { Aceh Tengah, Gayo Lues, Bener Meriah, Nias, Tapanuli Utara, Toba Samosir, } \\
\text { Dairi, Karo, Nias Selatan, Humbang Hasundutan, Pakpak Bharat, Samosir, Nias } \\
\text { Barat, Indragiri Hilir, Kerinci, dst }\end{array}$ \\
\hline Cluster 2 & 154 & $\begin{array}{c}\text { Simeulue, Aceh Singkil, Aceh Selatan, Aceh Tenggara, Aceh Timur, Aceh Barat, } \\
\text { Pidie, Bireuen, Aceh Utara, Aceh Barat Daya, Aceh Jaya, Pidie Jaya, Kota } \\
\text { Subulussalam, Mandailing Natal, Tapanuli Selatan, dst }\end{array}$ \\
\hline Cluster 3 & 173 & $\begin{array}{c}\text { Aceh Besar, Aceh Tamiang, Nagan Raya, Kota Banda Aceh, Kota Sabang, Kota } \\
\text { Langsa, Kota Lhokseumawe, Labuhan Batu, Asahan, Deli Serdang, Langkat, } \\
\text { Serdang Bedagai, Batu Bara, Labuhan Batu Selatan, Labuhan Batu Utara, dst }\end{array}$ \\
\hline Cluster 4 & 70 & $\begin{array}{c}\text { Kota Medan, Ogan Komering Ilir, Musi Banyuasin, Banyu Asin, Kota Palembang, } \\
\text { Lampung Selatan, Lampung Timur, Lampung Tengah, Kota Jakarta Timur, Bogor, } \\
\text { Sukabumi, Cianjur, Bandung, Garut, Tasikmalaya,dst }\end{array}$ \\
\hline
\end{tabular}

Untuk mengkategorikan atau membuat level hasil clustering, pertama yang harus dilakukan adalah melihat dari centroid masing- masing cluster. Lalu dilakukan pembacaan dengan cara mencari beberapa variabel bebas asal (kota / kabupaten) yang merupakan anggota masing- masing cluster dan memiliki jarak terdekat dengan koordinat centroid.

Dalam kasus ini variabel bebas berisikan rentang nilai atau prosentase dari 1 sampai 100 tentang kondisi kemiskinan tiap kota / kabupaten. Lalu dipilih variabel yang bersifat positive point of view atau dengan arti semakin tinggi nilai suatu variabel, maka semakin rendah dari penilaian kemiskinan. Kemudian dilakukan ratarata nilai variabel bebas dengan karakteristik positive point of view dari sampel variabel yang terdekat dengan koordinat centroid dan didapatkan hasil seperti berikut : 
Tabel 5

Leveling Cluster

\begin{tabular}{|c|c|c|}
\hline $\begin{array}{c}\text { Nama } \\
\text { Cluster }\end{array}$ & Rata- rata Nilai & $\begin{array}{c}\text { Leveling } \\
\text { Cluster }\end{array}$ \\
\hline Cluster 1 & 57,0952229 & 3 \\
\hline Cluster 2 & 57,11267201 & 2 \\
\hline Cluster 3 & 57,14660104 & 1 \\
\hline Cluster 4 & 57,09337744 & 4 \\
\hline
\end{tabular}

Dari tabel didapatkan bahwa Kabupaten / Kota pada Cluster 4 merupakan kelompok daerah dengan level cluster peringkat terakhir (peringkat 4) karena memiliki rata- rata nilai variabel dengan karakteristik positive point of view terendah, setelah disusul oleh Cluster 1, Cluster 2 dan yang terakhir Cluster 3.

Kabupaten / Kota pada Cluster 4 menjadi cluster yang seharusnya mendapat perhatian lebih dalam penanganan pengentasan kemiskinan. Sektor yang menjadi perhatian utama dalam pengentasan kemiskinan adalah dibidang pendidikan dilihat dari variabel tamatan pendidikan dan angka melek huruf yang rendah di Kabupaten / Kota pada Cluster 4. Pendidikan sendiri menjadi syarat administrasi dalam penyerapan tenaga kerja di sektor formal, selain itu pendidikan juga berperngaruh positif terhadap peluang dalam pembuatan lapangan pekerjaan yang membantu dalam pengentasan angka kemiskinan di Kabupaten / Kota di Indonesia.

\section{KESIMPULAN}

Proses PCA (Principal Component Analysis) dengan analisa Proporsi Kumulatif Varians dan minimum persentase keragaman data sebesar $80 \%$ maka didapatkan output berupa dimensi data baru PCA sebanyak 3 dimensi atau 3 variabel bebas baru dan antar variabel baru tersebut (PCA 0, PCA 1 dan PCA 2) tidak terdapat multikolinearitas setelah dilakukan uji korelasi. Proses pemilihan jumlah cluster dilakukan dengan metode Silhouette Coefficient dan didapatkan jumlah kluster terbaik sebanyak 4 kluster dengan nilai silhouette coefficient tertinggi ada pada nilai 0,320 .

Hasil dari analisa clustering dengan metode K-Means dengan variabel PCA 0, PCA 1 dan PCA 2 serta jumlah kluster sebanyak 4, didapatkan jumlah anggota clustering Kabupaten / Kota pada cluster 1 sebanyak 117, cluster 2 sebanyak 154, cluster 3 sebanyak 173 dan cluster 4 sebanyak 70 Kabupaten / Kota.

Dari ke empat cluster yang terbentuk dilakukan levelling interpretasi terhadap dan diketahui bahwa cluster 4 berada pada level 4 yang berarti bahwa pada cluster tersebut perlu perhatian utama dalam pengentasan kemiskinan, kemudian disusul oleh Cluster 1, Cluster 2 dan yang terakhir Cluster 3. Dan sektor utama yang diperlukan dalam pengentasan kemiskinan adalah pendidikan, karena di cluster 4 tingkat tamatan pendidikan dan angka melek baca memiliki rata- rata terendah karena rendahnya sektor pendidikan berdampak pula terhadap tingginya angka pengangguran.

\section{DAFTAR PUSTAKA}

Aljarah Ibrahim, Hosam Faris, Sayedali Mirjalili (2021). Evolutionary Data Clustering: Algorithms and Application.Brisbane:Springer

Asuero,A.G, Sayago A and Gonz'alez A. G. The Correlation Coefficient: An Overview. Critical Reviews in Analytical Chemistry, 36:41-59, 2006.

Febianto, Nugroho Irawan and Nico Dias Palasara (2019), Analisis Clustering K-Means Pada Data Informasi Kemiskinan Di Jawa Barat Tahun 2018, Jurnal SISFOKOM, Vol. 08, No. 02.

Jain A K, Dubes R C (1988). Algorithms for clustering data[M]. New Jersey: Prentice-Hall.

Jamal I. Daoud (2017), Multicollinearity and Regression Analysis, IOP Conf. Series: Journal of Physics: Conf. Series 949 (2017) 012009.

Kodinariyah Trupti M, Makwana Prashant R (2013). Review on determining number of Cluster in K-Means Clustering. International Journal of Advance Research in Computer Science and Management Studies. ISSN: 2321-7782

Nugroho Sigit (2008). Statistika Multivariat Terapan. Indonesa, Bengkulu:UNIB Press

Roflin Eddy, Ferani Eva Zulvia (2021). Kupas Tuntas Analisis Korelasi. Indonesia, Pekalongan:PT Nasaya Expanding Management. 
Wu, Junji (2012). Advances in K-means Clustering A Data Mining Thinking. Heidelberg: Springer Yusuf, Muhammad, Daris, Lukman. (2018). Analisis Data Penelitian Teori \& Aplikasi dalam Bidang Perikanan. Indonesia, Bogor: PT Penerbit IPB Press. 